УДК 343.9853

(C) 2018

Щербакова Н. С., кандидат ветеринарних наук,

Передера С. Б., кандидат ветеринарних наук,

Передера Ж. О., кандидат ветеринарних наук

Полтавська державна аграрна академія

Щербаков Є. А., адвокат, илен ради адвокатів Полтавської області

\title{
ЗМІНИ У ЗАКОНОДАВСТВІ УКРАЇНИ ЩОДО ПРИЗНАЧЕННЯ СУДОВО- ВЕТЕРИНАРНИХ ЕКСПЕРТИЗ ТА ПОРЯДКУ ЗАЛУЧЕННЯ ЕКСПЕРТІВ
}

\section{Рецензент - кандидат юридичних наук, адвокат, илен ради адвокатів Полтавської області Д. П. Таран}

\begin{abstract}
У статті наведені дані щзодо аналізу змін до кримінально-процесуального законодавства Украӥни в питаннях правових підстав проведення експертиз та порядку залучення експертів ветеринарної медицини. Встановлено, щзо зміни до кримінальнопрочесуального законодавства Украӥни в питаннях правових підстав проведення експертиз та порядку залучення експертів ветеринарної медицини показує систематичне наближення нормативно-правової бази України в кримінальному процесі до міжнародних норм і стандартів, і спрямовані на досягнення максимального рівня неупередженості з боку учасників кримінального судочинства.
\end{abstract}

Ключові слова: кримінально-прочесуальне законодавство, судово-ветеринарна експертиза, експерти ветеринарної медицини.

Постановка проблеми. Сучасна судововетеринарна експертиза - це самостійна частина ветеринарної науки, що вивчає ветеринарнобіологічні питання, які виникають у правоохоронних органах у процесі розслідування і судового розгляду кримінальних і цивільних справ. Існуючи як ветеринарна наука, судововетеринарна експертиза нерідко стикається 3 юридичними дисциплінами $[1,5,6]$.

Окрім того, експертна діяльність та судововетеринарна експертиза зокрема, має неухильно відповідати чинному законодавству та оперативно реагувати на всі зміни до чинного законодавства, що регламентують їі діяльність $[1,2]$.

Так, 03.10.2017 року Верховною Радою України ухвалено Закон «Про внесення змін до Господарського процесуального кодексу України, Цивільного процесуального кодексу України, Кодексу адміністративного судочинства України та інших законодавчих актів», яким, зокрема, внесено зміни до кримінального процесуального кодексу України в частині підстав проведення експертиз та порядку залучення експертів [3].

Такі зміни до кримінального процесуального законодавства значно змінюють процедуру та правові підстави призначення судововетеринарної експертизи, що обов'язково мають знати та використовувати в своїй діяльності судово-ветеринарні експерти.

Аналіз змін у законодавстві по даній темі. Для аналізу змін у кримінально-процесуальному законодавстві України першочергово варто порівняти безпосередньо нормативно-правові акти, до яких внесено зміни законодавцем.

Підстави для проведення експертиз у кримінальному процесі, зокрема i судово-ветеринарних, є норма статті 242 Кримінально-процесуального кодексу України, де в частині 1 до внесення відповідних змін зазначалося наступне:

«Експертиза проводиться експертом за зверненням сторони кримінального провадження або за дорученням слідчого судді чи суду, якщо для 3'ясування обставин, що мають значення для кримінального провадження, необхідні спеціальні знання. Не допускається проведення експертизи для з'ясування питань права».

Натомість, та ж частина 1 статті 242 Кримінально-процесуального кодексу України в новій редакції виглядає наступним чином:

«Експертиза проводиться експертною установою, експертом або експертами, за дорученням слідчого судді чи суду, наданим за клопотанням сторони кримінального провадження або, якщо для 3'ясування обставин, що мають значення для кримінального провадження, необхідні спеціальні знання. Не допускається проведення експертизи для з'ясування питань права».

Відповідні зміни відбулися і в частині 2 статті 242 Кримінально-процесуального кодексу України, де до внесення змін норма мала наступний вигляд:

«Слідчий або прокурор зобов'язаний звернутися до експерта для проведення експертизи щодо:...» 


\section{ВЕТЕРИНАРНА МЕДИЦИНА}

У свою чергу, в новій редакції дана норма виглядає наступним чином:

«Слідчий або прокурор зобов'язані звернутися 3 клопотанням до слідчого судді для проведення експертизи щодо:...».

У відповідності до логіки правових перетворень зміни відбулися і в порядку залучення експерта до проведення судових експертиз.

Так, у минулому редакція статті 243 Кримінально-процесуального кодексу України виглядала наступним чином:

«1. Сторона обвинувачення залучає експерта за наявності підстав для проведення експертизи, у тому числі за клопотанням сторони захисту чи потерпілого.

2. Сторона захисту має право самостійно залучати експертів на договірних умовах для проведення експертизи, у тому числі обов'язкової.

3. Експерт може бути залучений слідчим суддею за клопотанням сторони захисту у випадках та в порядку, передбачених статтею 244 цього Кодексу.»

Натомість, згідно з вищевказаним Законом, стаття 243 Кримінально-процесуального кодексу України, має наступний вигляд:

«Експерт залучається за наявності підстав для проведення експертизи за дорученням слідчого судді чи суду, наданим за клопотанням сторони кримінального провадження.» $[3,4]$.

Метою дослідження $\epsilon$ аналіз змін до кримінально-процесуального законодавства України в питаннях правових підстав проведення експертиз та порядку залучення експертів ветеринарної медицини.

Результати досліджень. Порівнюючи підстави для призначення судових експертиз, зазначених в статті 242 Кримінально-процесуального кодексу України, в першу чергу вбачається зміна суб'єкта безпосереднього звернення до експерта чи експертної установи.

Якщо раніше звернення до експерта про проведення експертизи, в тому числі судововетеринарної, відбувалося безпосередньо від сторони кримінального провадження і лише допускалася можливість надання доручення на проведення такої експертизи судом, то в новій редакції вбачається значне звуження суб'єктів такого звернення.

В подальшому, експертизи, в тому числі судово-ветеринарні, мають проводитися виключно за дорученням слідчого судді чи суду, що в свою чергу впливає на інші норми Кримінальнопроцесуального кодексу України пов'язані з підставами та порядком призначення та проведення судових експертиз.
Так, у частині 2 статті 242 КПК України обов'язок слідчого чи прокурора про звернення безпосередньо до експерта про проведення судової експертизи змінився на обов'язок звернутися до слідчого судді, тобто суду, з клопотанням про призначення такої судової експертизи.

Вищевказані зміни потягли за собою і відповідні зміни в самому порядку залучення експерта для проведення судової експертизи, що викладені в статті 243 Кримінально-процесуального кодексу України.

Так, у минулій редакції, саме на сторону обвинувачення, тобто на слідчого чи прокурора, було покладено функцію залучення експерта для проведення експертизи, в тому числі і судововетеринарної, і лише допускалася можливість звернення сторони захисту до експерта на договірних умовах, що фактично виводило даний вид експертиз за межі терміну «судова експертиза».

Зміни ж до даної норми права встановили жорсткі обмеження, щодо залучення експертів для проведення саме судових експертиз по суб'єкту, що має таке право.

У новій редакції вищевказаної норми чітко визначається виключне право суду чи слідчого судді на залучення експертів для проведення саме судових експертиз, що в певній мірі відповідає самій назві проведення таких експертиз.

Водночас вищевказаними нововведеннями повністю урівнюються права сторін обвинувачення та захисту на звернення до суду чи слідчого судді з клопотаннями про призначення судових експертиз та залучення відповідних експертів.

Вищевикладені зміни до кримінальнопроцесуального законодавства України відповідають загальним тенденціям максимального наближення законодавства України до міжнародних стандартів судочинства, важливу роль в якому віднесена залученню експертів для встановлення об'єктивної істини.

Міжнародна практика залучення експертів вказує на необхідність розподілу повноважень, у процесі призначення судових експертиз, між різними гілками влади, а саме між виконавчою та судовою.

Саме така модель залучення експертів має сприяти підвищенню рівня прозорості та законності діяльності системи правосуддя в кримінальному процесі, що знижує рівень ризиків корупційної складової.

За таких умов експертам, що залучаються для проведення судових експертиз у кримінальному процесі, зокрема судово-ветеринарних, необхідно уважно досліджувати законність призначення 


\section{ВЕТЕРИНАРНА МЕДИЦИНА}

таких експертиз та уважно досліджувати правові підстави такого залучення.

\section{Висновки:}

1. Аналіз змін до кримінально-процесуального законодавства України в питаннях правових підстав проведення експертиз та порядку залучення експертів ветеринарної медицини показує систематичне наближення нормативно-правової бази України в кримінальному процесі до міжнародних норм і стандартів.

\section{БІБЛІОГРАФІЯ}

1. Зон Г. А. Судово-ветеринарна експертиза : навч. посіб. / Г. А. Зон. - Суми : ВВП «Мрія-1», 2002. $-258 \mathrm{c}$.

2. Експертизи у судовій практиці : наук.практ. посіб. / [ред. В. Г. Гончаренко]. - КНДІ суд. експертиз, Акад. адвокатури України. - 2-е вид., перер. і доп. - К. : Юрінком Інтер, 2010. $400 \mathrm{c}$.

3. Закон України від 25.02.1994 та від 20.01.2018, № 4038-XII «Про судову експертизу» [Електронний ресурс] / Верховна Рада України. Офіц. вид. - Режим доступу : http://zakon2.rada.gov.ua/laws/show/4038-12.

4. Інструкція про призначення та проведення судових експертиз та Науково-методичні рекомендації з питань підготовки та призначення судових експертиз та експертних досліджень, за-
2. Зміни, що внесені у відповідних нормах права стосовно підстав проведення експертиз та порядку залучення експертів, зокрема спрямовані на досягнення максимального рівня неупередженості з боку учасників кримінального судочинства.

Такі зміни спрямовані ще й на зменшення вірогідності корупційної складової в процесі залучення експертів та призначенні судових експертиз, що на даний час знаходиться серед першочергових завдань держави.

тверджені наказом Міністерства юстиції України від 08.01.1998 № 53/5 (у ред. наказу від 26.12.2012 № 1950/5) [Електронний ресурс] / Верховна Рада України. - Режим доступу : URL : http://zakon4.rada.gov.ua/laws/show/z0705-98.

5. Судово-ветеринарна експертиза / Офіційний сайт Кафедри нормальної та патологічної морфології і судової ветеринарії ЛНУВМ та БТ імені С. 3. Гжицького [Електронний ресурс]. - Режим доступу : http://vetpathology.lviv.ua/disciplini/29sudovo-veterynarna-ekspertyza.html.

6. Яценко I. В. Судова ветеринарна медицина наука i навчальна дисципліна / I. В. Яценко, М. М. Бондаревський, В. В. Кам'янський // Науково-технічний бюлетень НДЦ біобезпеки та екологічного контролю ресурсів АПК. - 2012. T. 1. - №1. - C. 98-112. 